\title{
Comparison of trauma on survivors of sexual assault and intimate partner violence in Limpopo
}

\author{
Authors: \\ Mashudu Davhana-Maselesele ${ }^{1}$ \\ Sylvester Madu ${ }^{2}$ \\ Gail E. Wyatt ${ }^{3}$ \\ John K. Williams ${ }^{3}$ \\ Lufuno Makhado \\ Lauren $\mathrm{H}$. Wong

\section{Affiliations:} \\ ${ }^{1}$ Rectorate, North-West \\ University, Mafikeng Campus, \\ South Africa \\ ${ }^{2}$ Department of Psychology, \\ University of Limpopo, \\ South Africa \\ ${ }^{3}$ Department of Psychiatry \\ and Biobehavioral Sciences, \\ UCLA-Semel Institute for \\ Neuroscience and Human \\ Behavior, United States \\ ${ }^{4}$ Department of Nursing \\ Science, North-West \\ University, Mafikeng Campus, \\ South Africa \\ ${ }^{5}$ Department of Psychology, \\ UCLA-Semel Institute for \\ Neuroscience and Human \\ Behavior, United States \\ Correspondence to: \\ Mashudu Davhana-Maselesele \\ Email: \\ davhana2@webmail.co.za \\ Postal address: \\ Private Bag X2046, Mmabatho \\ 2735, South Africa \\ Dates: \\ Received: 23 June 2012 \\ Accepted: 02 Oct. 2013 \\ Published: 20 June 2014 \\ How to cite this article: \\ Davhana-Maselesele, M., \\ Madu, S., Wyatt, G.E., \\ Williams, J.K., Makhado, \\ L. \& Wong, L.H., 2014, \\ 'Comparison of trauma on \\ survivors of sexual assault \\ and intimate partner violence \\ in Limpopo', Health SA \\ Gesondheid 19(1), Art.\#683, \\ 11 pages. http://dx.doi. \\ org/10.4102/hsag.v19i1.683

\section{Read online:} \\ Scan this QR \\ code with your \\ smart phone or \\ mobile device \\ to read online.
}

Background: Gender-based violence is a challenge in South Africa, despite available interventions. Caring for the survivors of both forms of violence is critical for ensuring their speedy recovery.

Objectives: To compare the effects of trauma on female survivors of sexual assault versus those experienced by survivors of physical assault by their intimate partners.

Method: A quantitative cross-sectional comparative study design was used to compare 30 sexually-assaulted women and 30 physically-assaulted women regarding depressive symptoms, posttraumatic stress disorder and coping styles three months after the incident. Semi-structured interviews were conducted with the survivors of both types of assault and the Beck Depression Inventory posttraumatic stress disorder checklist and Brief COPE Inventory were administered in order to obtain quantitative data. Both parametric and non-parametric statistics were employed. Ethical measures were adhered to throughout the research process.

Results: A significantly-higher proportion of sexually-assaulted women disclosed the incident to family ( $p=0.021)$. The majority of sexually- $(90 \%)$ and physically- $(86 \%)$ assaulted women were likely to recall the incident. Sexually-assaulted women had a significantly-higher mean for avoidance/numbness $(p<0.001)$ and physical-assaulted women in arousal $(p>0.051)$. About $41 \%$ of sexually-assaulted participants reported severe depression. Findings confirmed that sexual assault is more personal whilst physical assault is more interpersonal. If physicallyassaulted women were removed from the perpetrators they recovered faster than sexuallyassaulted women. Their stay with the perpetrators may perpetuate the violence.

Conclusion: The need for counselling and support for the survivors of both traumas was recommended. All stakeholders should be educated to provide support to survivors of both traumas.

Agtergrond: Ten spyte daarvan dat daar intervensies beskikbaar is, bly geslagsgebaseerde geweld ' $n$ uitdaging in Suid-Afrika. Die versorging van die oorlewendes geweld is van kritieke belang om die oorlewendes se spoedige herstel te verseker.

Doelwitte: Die doel was om die gevolge van trauma op die vroulike slagoffers van seksuele aanranding te vergelyk met die trauma wat die oorlewendes van fisiese aanranding ervaar het.

Metode: 'n Kwantitatiewe dwarssnit ontwerp is gebruik om 30 seksueel aangerande vroue en 30 fisiek aangerande vroue te vergelyk sover dit depressiesimptome, posttroumatiese stresversteuring en coping styl betref drie maande na die voorval plaasgevind het. Semigestruktureerde onderhoude is gevoer met die oorlewendes van beide soorte aanvalle, terwyl die Beck depressie-inventaris, die kontrolelys vir posttroumatiese stresversteuring en die bondige COPE-inventaris afgeneem is om kwantitatiewe data te bekom. Sowel parametriese as nie-parametriese statistiek is gebruik. Etiese vereistes is regdeur die navorsingsproses nagekom.

Resultate: 'n Aansienlik hoër persentasie seksueel aangerande vrouens het hulle gesin oor die voorval ingelig $(p=0.021)$. Die meeste seksueel $(90 \%)$ en fisiek $(86 \%)$ aangerande vrouens het die voorval onthou. Seksueel aangerande vrouens toon ' $n$ aansienlik hoër gemiddelde vir vermyding of gevoelloosheid $(p<0.001)$ en fisiese aangerande vrouens het ' $n$ hoër gemiddelde vir opwekking $(p>0.051)$. Sowat $41 \%$ van die seksueel aangerande deelnemers meld erge depressie. Die studie bevestig dat seksuele aanranding persoonliker is, terwyl fisieke aanranding meer interpersoonlik is. As fisiek aangerand vroue van die oortreders verwyder word, herstel hulle vinniger as die seksueel aangerande vroue. As hulle by die oortreders bly, kan die geweld voortduur.

Gevolgtrekking: Die noodsaak aan berading en ondersteuning vir beide groepe oorlewendes word aanbeveel. Alle belanghebbendes moet opgevoed word om ondersteuning aan oorlewendes te bied. 


\section{Introduction and background}

South Africa is facing the challenge of having to provide services to the victims of both sexual and physical assault. These are common crimes that women and children are exposed to in their daily lives (Killian et al. 2007:585).

Several studies have revealed that intrusion into physical privacy through sexual assault predisposes the victim to a higher risk of contracting HIV and sexually-transmitted Infections (STIs), as well as a higher risk of unwanted pregnancy, abortion, sexual dysfunction, promiscuity, prostitution and sexual revictimisation, than those women who are physically assaulted only (Baker et al. 1990; McCloskey 1997; Zierler, Witbeck \& Mayer 1996). These effects are not normally associated with physical assault and can result in higher rates of post-traumatic stress disorder (PTSD) and depression, leading to more negative coping styles (Johnson \& Benight 2003:570). Sexual assault is therefore more destructive as it is more prevalent and more prolonged than physical assault (Herman, Perry \& Van der Kolk 1989). It was of utmost importance that a comparative study be conducted which will assist in assessing the levels of trauma as a result of either sexual or physical assault.

Sexual assault has been described as a traumatic experience which can seriously disrupt the lives of victims (Dye \& Roth 1990:191; Regehr, Marziali \& Jansen 1999:171; Ullman \& Brecklin 2002:261) and is believed to be more traumatic than physical assault because the features of the incident are extremely personal. Invasion of the body brings about shame, potential loss of virginity and is seen as a dirty act. In addition, physical morbidity and mental health problems were identified as being some of the negative effects of sexual assault (Kalichman et al. 2002:291; Ullman \& Brecklin ibid:261; Weist et al. 2007:2; Wiebe et al. 2000:641). Both sexual assault and physical violence are harmful, being a destructive violation of human rights. The victim blames herself, feeling that if she had not put herself into a situation of vulnerability, the assault would not have happened. Robertson (1998) describes the impact of rape on the victims as the most devastating personal trauma, in which the victims' lives have been shattered and their psychological and physical privacy have been invaded, making the victim experience more feelings of shame than victims of physical assault.

Literature (Campbell 2002) revealed that $40 \%$ - 50\% of physically-assaulted women are also sexually assaulted by their intimate partners. Other authors, such as Jewkes and Abrahams (2002), hold a different view, arguing that women who often report physical assault may not report forced sex as they would regard forced sex as 'normal'. Most women who are used to the context in which their partners force them to do things would not regard forced sex as rape. Some believe that if a man has paid lobola (money paid to parents of the girl before marrying her), coerced sex will mean fulfilling conjugal rights or 'wifely duties' (Mahoney \& Williams 1998). Rape, according to the traditional community, is forced sex by any person other than an intimate partner. This means that women would not report 'marital rape', as they perceive it to be providing for the sexual needs of their husbands. In most African traditional communities it is believed that women have sex for reproduction and men for enjoyment. This study took into consideration the traditional beliefs and cultural practices within Limpopo Province. It is for this reason that this study focused on assessing the levels of trauma as a result of sexual assault by strangers versus trauma as a result of physical assault by intimate partners.

Dealing with the trauma of sexual and physical assault by intimate partners is further influenced by the socio-cultural environment to which the individual is exposed. The way in which society views these types of assault influences how the individual perceives the trauma. The societies which judge these women and often blame them for the act, in the sense that they contributed in one way or another, cause women to refrain from seeking help and they often blame themselves (Heise, Moore \& Toubia 1996).

Similar studies conducted by Roth et al. (1997), where a comparison of sexually- and physically-assaulted individuals with symptoms of Complex PTSD (CP) was carried out, revealed that women who had been sexually abused had consistent symptoms of $\mathrm{CP}$ as a result of the following:

- shame and secrecy, which may be intensified in sexuallyabusive situations

- boundary violations and intrusiveness of sexual abuse may be greater

- dissociation may be used more often in order to cope with sexual violations

- sexual abuse may interact with cultural constructions about sexuality to influence women's constructions of themselves and others (Lebowitz \& Roth 1994).

The social and cultural contexts to which victims are exposed determine their recovery from both sexual and physical assault by an intimate partner. Physical assault by a partner is usually regarded as being a private matter and, when reported, it is deemed to be akin to washing one's dirty linen in public. This makes victims of physical assault reluctant to report perpetrators to the police. Seymour (2002) states that physically-abused women are reluctant to reveal their situation without careful consideration. This is the case because of fear of judgement, embarrassment and uncertainty about whether they will be able to deal with the case effectively.

\section{Problem statement}

Statistics on sexual and physical assault crimes are very unreliable because of the massive under-reporting of cases. A community-based prevalence study conducted in three provinces of South Africa found that $26.8 \%$ of women in the Eastern Cape, $28.4 \%$ of women in Mpumalanga and 19.1\% of women in Limpopo Province had been physically abused during their lifetime by a current or ex-partner (Jewkes et al. 1999). Despite these high numbers, sexual assault is still regarded as being the most under-reported and underprosecuted crime (Killian et al. 2007:585). According to 
personal experience during voluntary service in the Vhembe district in the Limpopo Province, between 40 and 46 women reported sexual assault on a monthly basis, whilst those experiencing domestic violence ranged from 100 to 120 per month. It is difficult to obtain statistics on domestic violence as records from the police station report lower rates of physical assault than the statistics from the trauma centre within the same district; this is because of classification of crimes by the police which makes it difficult to describe the type of assault clearly.

Domestic violence is not codified as a separate criminal offence but falls under common assault or assault with intent to do grievous bodily harm (Moult \& Artz 2011). Physicallyassaulted women may report injuries to the trauma centre without reporting the case to the police; this therefore leads to a lesser number of physical assault cases being reported to the police. The Limpopo Province has very few trained healthcare personnel who can deal effectively with trauma as result of sexual and physical assault. As a result of the shortage of mental healthcare practitioners, not every person who is sexually or physically assaulted will have a chance of being seen by a psychologist. They are often only referred to a psychologist by the survivor support officer (SSO), who is a trauma counsellor.

Within the context of Limpopo Province, survivors who reported sexual assault at the clinic had experienced stranger rape and rape by non-strangers who were not intimate partners, whilst those who reported physical assault were assaulted by their intimate partners. It was, therefore, necessary to conduct research in this area in order to assess the differences in severity of depression, PTSD and coping styles between these two groups.

There is a dearth of literature in South Africa on comparative studies between sexual and physical abuse regarding the levels of depression, PTSD and negative or maladaptive coping styles. This study focused on comparing the two sources of trauma so as to bridge the knowledge gap that exists, in order to develop interventions to address the needs of survivors of sexual assault as well as the needs of survivors of physical assault at the hands of their intimate partners. This study intends to answer the following questions:

- Do the levels of depression and PTSD amongst sexuallyand physically-assaulted women differ?

- What are the coping styles of these women?

- What kind of support do they receive?

- How does the socio-cultural environment influence their coping?

\section{Aim and objectives}

The aim of this study is to compare the levels of PTSD and depression, as well as coping styles between victims of sexual and physical assault. This was obtained through the following objectives:

- To compare 30 survivors of sexual assault with 30 survivors of physical assault regarding depressive symptoms.
- To compare 30 survivors of sexual assault with 30 survivors of physical assault regarding PTSD.

- To examine coping styles that mediate trauma and emotional adjustment.

- To assess the impact of socio-cultural support amongst the survivors of sexual and physical assault.

\section{Research design and method}

A quantitative cross-sectional design was used to compare 30 participants who had reported sexual assault by either strangers or people known to them who were not intimate partners with 30 participants who reported physical assault by intimate partners at a trauma centre in the Vhembe District of the Limpopo Province of South Africa.

Vhembe District has two trauma centres that are under the auspices of the Thohoyandou Victim Empowerment Programme (TVEP), one at a community hospital and the other one at a referral hospital within the district. The trauma centre at the referral hospital within the district was the preferred venue for the study as the participants were more easily accessible. Participants with similar background characteristics were selected in order to match the samples in terms of demographic characteristics, socio-economic status and ethnicity. The two groups were compared in order to assess the differences in their levels of depression and PTSD, as well as their coping styles.

All women who reported sexual and/or physical assault and who gave consent to participate in the study were included in the study. It should be noted that the sample was not necessarily representative of the whole province but it is reflective of women at that trauma centre who reported sexual assault by someone other than intimate partners and those that were physically assaulted by intimate partners. Women who presented themselves at the Tshilidzini trauma centre were informed about the study by the SSO who worked at the trauma centre. The SSO obtained permission from the women to give their names and contact information to the researcher and the researcher then contacted the potential participants telephonically in order to determine whether they met the study eligibility criteria.

Inclusion criteria for survivors of sexual assault were as follows:

- The survivor had reported to the clinic regarding recent sexual assault and/or rape (in the previous three months).

- No history of sexual assault by intimate partners.

- No history of physical assault by an intimate partner was reported. Records of these women confirmed that they had only reported sexual assault.

- They were aged between 18 and 45 years (child-bearing age).

Inclusion criteria for the survivors of physical assault were as follows:

- They had reported recent physical assault by their intimate partner (in the previous three months).

- They had no history of sexual assault.

- They were aged between 18 and 45 years (child bearing age). 
Patient records were consulted to confirm whether a potential participant met the criteria. However, the sample was small as this was influenced by the exclusion criteria which were stated as being no history of sexual assault for physicallyassaulted victims and no history of physical assault for sexually-assaulted victims. The researcher then made an appointment to meet those who met the criteria, preferably at the trauma centre. If this was not possible, the appointment was held at a place that was convenient for the potential participants. Information about the study was given and permission was sought before interviews were conducted. In addition, permission was sought for the interviews to be audio recorded. Participants were reimbursed for any transport costs incurred.

\section{Data collection}

The instruments used for data collection were developed and translated into Tshivenda (a local language) by a clinical psychologist who speaks Tshivenda and then given to a language editor for editing. Participants were interviewed on the questionnaire items by the researcher in order to ensure that they all understood the questions and also to accommodate those who could not read and write. Openended questions were asked, where the participants were invited to explain in detail what had happened to them.

The following instruments were used for quantitative data collection:

Demographic measures were used in order to assess the age, ethnicity, literacy rate, income and marital status of the participants.

Semi-structured interviews were used to interview the participants who reported sexual assault by known individuals or strangers or physical assault by their intimate partners so that they could explain in their own words what had happened to them.

The PTSD Checklist - Specific Version (PCL-S) (Blanchard et al. 1996) was used to assess PTSD symptoms by asking participants to report on how much they were troubled in the month after they had been sexually and/or physically assaulted. The PTSD Checklist consists of 17 items which are rated on a 5-point Likert scale for degree of bother for each symptom in the last month $(1=$ not at all; 2 = a little bit; 3 = moderately; 4 = quite a bit; 5 = extremely). The PCL-S was found to be reliable with Cronbach's alpha values exceeding 0.70 , which is the widely-accepted reliability limit (Blanchard et al. ibid:672). Cronbach's alpha values were 0.740 with the 17 items.

The Beck Depression Inventory (BDI) (Beck, Steer \& Carbin 1988) is a self-administered 21-item self-report scale measuring supposed manifestations of depression, such as sadness, pessimism, insomnia, et cetera. Each item was scored on a $0-3$ point scale which indicated the severity of symptoms, with 0 indicating an absence of depressive symptoms and 3 indicating severe depressive symptoms. The BDI takes about 10 minutes to complete although clients require a fifth- to sixth-grade reading age in order to understand the questions adequately. The BDI has been used widely and has wellestablished validity and reliability. Bumberry, Oliver and McClure (1978) report a high reliability and validity of BDI with a coefficient alpha of 0.85 .

The Brief COPE Inventory (Brief COPE) (Carver 1997) is an abbreviated version of the COPE Inventory as earlier patient samples became impatient when responding to the full instrument (both because of the length and redundancy of the full instrument and because of the overall time burden of the assessment protocol). Each item was scored on a 4-point scale: 1 = I haven't been doing this at all; $2=$ I have been doing this a little bit; $3=$ I have been doing this a medium amount; 4 = I have been doing this a lot. The Brief COPE was found to be reliable with Cronbach's alpha values exceeding 0.70 , which is the-widely accepted reliability limit (Carver ibid). Cronbach's alpha values were 0.769 with the 28 items.

\section{Data analysis}

The Statistical Package for Social Science (SPSS) version 16.0 (SPSS 2007) was used to analyse the data. The $t$-test was used to compare the average scores of the two different groups, namely the sexually- and physically-assaulted women.

\section{Ethical consideration}

After approval by the Institutional Review Boards (IRB) for the protection of human research subjects from the University of California, Los Angeles (UCLA), the Limpopo Provincial Department of Health and Social Development and the Thohoyandou Victim Empowerment Programme (TVEP), as well as the hospital where the trauma centre is based, recruitment of participants started.

The researcher ensured that all collected information was stored and used in such a manner as would ensure the confidentiality and privacy of all participants at all costs, bearing in mind the sensitivity of the research. The names of the participants were not divulged and data were only accessed by the researcher.

The consent form was translated into Tshivenda, the language which the participants understood best. Participants were recruited as they visited the trauma centre. Information about the study was provided and, if they agreed, a written consent form was signed. Participants were not compensated as this was not expected and it could be seen as a form of coercion. They were, however, reimbursed for transport and given refreshments during the interviews.

The risks of the study were that a participant might be uncomfortable relating a particularly traumatic story and become emotionally distraught when talking about a traumatic event. This was a common occurrence, but the researcher gave the participants sufficient time and support. Participants who had suicidal ideation were referred to a psychologist and those that reported social problems related to maintenance of their children were referred to a 
social worker. All participants were assured that they could terminate the interviews and withdraw at any time.

\section{Results and analysis}

Table 1 shows the demographic profile of the study participants and provides a comparison of the proportion of individuals in each category.

The ages of the participants in both groups ranged from 18 to 45 years old. The mean age of the physically-assaulted participants was 29 years (standard deviation [SD], 7.7), which was significantly higher than the mean age of the sexuallyassaulted persons (24 years; SD, 7.3). Most participants were Venda $(97 \% ; n=57)$. Approximately $78 \%(n=23)$ of the sexually-assaulted women had matric as compared with those who had been physical assaulted $(48 \% ; n=14)$. The majority of sexually-assaulted women $(76 \% ; n=23)$ had never been married, whereas the majority of those who had been physically assaulted were married $(77 \% ; n=23)$. A significant difference was noted between those women who had been sexually and physically assaulted with regard to age $(p=0.026)$, marital status $(p<0.001)$ and current relationship status $(p<0.001)$, whilst no significant difference was seen with regard to employment $(p=0.539)$, education $(p=0.079)$ and ethnicity $(p=0.0322)$.

In Table 2, the disclosure status of sexual and physical assault groups revealed no significant difference with regard to disclosure to anyone, a friend, the police or a local nongovernmental organisation. With both kinds of assault, friends were the least likely to be told. A significantly higher proportion of sexually-assaulted women, as compared with physicallyassaulted women, had told their family $(p=0.005)$ and/or community members $(p=0.021)$ about the incident. In contrast, a significantly higher proportion of physically-assaulted persons, as compared with sexually-assaulted women, had told a nurse or doctor $(p=0.000)$ about the incident.

One physically-assaulted participant had this to say regarding reporting to the doctor or nurse:

'I was rushed to the hospital as I had a broken left arm and I told the doctor that I was beaten by my husband.' (P5, Female, 33)

A high proportion of both groups reported being satisfied with the services they received. Services for the sexuallyassaulted women included STI prophylaxis, HIV testing and post-exposure prophylaxis as well as counseling and support. Services for the physically-assaulted women included treatment of injuries as well as referral to a social worker where necessary. Almost all of the physically-assaulted women $(90 \% ; n=27)$ reported that they were 'very satisfied', as compared with only half of the sexually-assaulted victims (50\%; $n=15)$. Over two-thirds of the sexually-assaulted individuals were 'very satisfied' with doctors $(73 \% ; n=19)$ and nurses $(69 \% ; n=18)$ respectively.

Regarding the assault experience, almost all the participants reported that they still thought about it. Sexually- (90\%; $n=27)$ and physically- $(86 \% ; n=26)$ assaulted individuals were more likely to think about the incident when they were alone. One participant who was physically assaulted said:

'I am so scared as I do not know what he will say to me when he comes home on Friday. I no longer look forward to his home coming.' (P1, Female, 28)

On the other hand, sexually-assaulted individuals were least likely to get nightmares about the incident whilst physicallyassaulted individuals were least likely to think about their assault when they heard about a similar incident. Sexuallyassaulted women were, however, more likely to think about their assault when they heard about a similar incident than the physically-assaulted ones.

TABLE 1: Demographic characteristics of participants by type of assault.

\begin{tabular}{|c|c|c|c|c|}
\hline \multirow[t]{2}{*}{ Demographic } & \multirow[t]{2}{*}{ Characteristics } & \multicolumn{2}{|c|}{ Type of assault } & \multirow{2}{*}{$\begin{array}{c}x^{2} \\
(p \text {-value })\end{array}$} \\
\hline & & Sexual assault & Physical assault & \\
\hline \multirow[t]{3}{*}{ Age } & Minimum & 18 & 18 & \multirow{3}{*}{$\begin{array}{l}30.051 \\
(0.026)\end{array}$} \\
\hline & Maximum & 45 & 45 & \\
\hline & Mean (SD) & $24(7.3)$ & $29(7.7)$ & \\
\hline \multirow{2}{*}{$\begin{array}{l}\text { Ethnicity } \\
(N=60)\end{array}$} & Venda & $97 \%(29)$ & $100 \%(30)$ & \multirow{2}{*}{$\begin{array}{c}0.983 \\
(0.322)\end{array}$} \\
\hline & Shangaan/Tsonga & $3 \%(01)$ & $0 \%(00)$ & \\
\hline \multirow{3}{*}{$\begin{array}{l}\text { Education } \\
(N=60)\end{array}$} & None & $17 \%(05)$ & $37 \%(11)$ & \multirow{3}{*}{$\begin{array}{c}5.079 \\
(0.079)\end{array}$} \\
\hline & Matric & $78 \%(23)$ & $48 \%(14)$ & \\
\hline & Basic degree & $5 \%(02)$ & $15 \%(05)$ & \\
\hline \multirow{5}{*}{$\begin{array}{l}\text { Employment } \\
(N=60)\end{array}$} & Working full time & $22 \%(7)$ & $15 \%(05)$ & \multirow{5}{*}{$\begin{array}{l}3.111 \\
(0.539)\end{array}$} \\
\hline & Housewife & $22 \%(7)$ & $22 \%(07)$ & \\
\hline & Attending school & $0 \%(00)$ & $19 \%(05)$ & \\
\hline & Unemployed & $56 \%(16)$ & $37 \%(11)$ & \\
\hline & Something else & $0 \%(00)$ & $7 \%(02)$ & \\
\hline \multirow{5}{*}{$\begin{array}{l}\text { Marital status } \\
(N=60)\end{array}$} & Married & $16 \%(05)$ & $77 \%(23)$ & \multirow{5}{*}{$\begin{array}{l}30.933 \\
(0.000)\end{array}$} \\
\hline & Separated & $4 \%(01)$ & $10 \%(03)$ & \\
\hline & Widowed & $4 \%(01)$ & $0 \%(00)$ & \\
\hline & Never married & $76 \%(23)$ & $7 \%(02)$ & \\
\hline & Cohabiting & $0 \%(00)$ & $6 \%(02)$ & \\
\hline \multirow{4}{*}{$\begin{array}{l}\text { Status of } \\
\text { current } \\
\text { relationship } \\
(N=60)\end{array}$} & $\begin{array}{l}\text { Living with } \\
\text { partner }\end{array}$ & $16 \%(05)$ & $79 \%(24)$ & \multirow[t]{4}{*}{$\begin{array}{l}34.549 \\
(0.000)\end{array}$} \\
\hline & $\begin{array}{l}\text { Has regular } \\
\text { partner }\end{array}$ & $0 \%(00)$ & $14 \%(04)$ & \\
\hline & $\begin{array}{l}\text { Dates } \\
\text { occasionally }\end{array}$ & $20 \%(06)$ & $7 \%(02)$ & \\
\hline & $\begin{array}{l}\text { No relationship in } \\
\text { last three months }\end{array}$ & $64 \%(19)$ & $0 \%(00)$ & \\
\hline
\end{tabular}

$x^{2}$, Chi-square; $p$-value, the attained level of significance; SD, standard deviation.

TABLE 2: Comparison of the pattern of disclosure of assault by persons who have been physically- and sexually assaulted.

\begin{tabular}{|c|c|c|c|c|}
\hline \multirow{2}{*}{$\begin{array}{l}\text { Patterns of } \\
\text { disclosure }\end{array}$} & \multirow[t]{2}{*}{ Answer } & \multicolumn{2}{|c|}{ Type of assault } & \multirow{2}{*}{$\begin{array}{c}x^{2} \\
(p \text {-value })\end{array}$} \\
\hline & & Sexual assault & Physical assault & \\
\hline \multirow{2}{*}{$\begin{array}{l}\text { Did you tell } \\
\text { anyone about } \\
\text { your assault? } \\
(N=59)\end{array}$} & Yes & $100 \%(30)$ & $93 \%(27)$ & \multirow{2}{*}{$\begin{array}{c}2.001 \\
(0.492)\end{array}$} \\
\hline & No & $0 \%(00)$ & $7 \%(02)$ & \\
\hline \multirow{2}{*}{$\begin{array}{l}\text { I told my friend } \\
\text { about my } \\
\text { assault }(N=60)\end{array}$} & Yes & $3 \%(01)$ & $0 \%(00)$ & \multirow{2}{*}{$\begin{array}{c}1.017 \\
(1.000)\end{array}$} \\
\hline & No & $97 \%(29)$ & $100 \%(30)$ & \\
\hline \multirow{2}{*}{$\begin{array}{l}\text { I told my family } \\
\text { about my assault } \\
(N=60)\end{array}$} & Yes & $67 \%(20)$ & $30 \%$ (09) & \multirow{2}{*}{$\begin{array}{c}8.076 \\
(0.005)\end{array}$} \\
\hline & No & $33 \%(10)$ & $70 \%(21)$ & \\
\hline \multirow{2}{*}{$\begin{array}{l}\text { I told my } \\
\text { community } \\
\text { member(s) } \\
\text { about my } \\
\text { assault }(N=60)\end{array}$} & Yes & $33 \%(10)$ & $7 \%(2)$ & \multirow{2}{*}{$\begin{array}{c}7.162 \\
(0.021)\end{array}$} \\
\hline & No & $67 \%(20)$ & $93 \%(28)$ & \\
\hline \multirow{2}{*}{$\begin{array}{l}\text { I told the police } \\
\text { about my assault } \\
(N=60)\end{array}$} & Yes & $27 \%(08)$ & $40 \%(12)$ & \multirow{2}{*}{$\begin{array}{c}1.200 \\
(0.412)\end{array}$} \\
\hline & No & $73 \%(22)$ & $60 \%(18)$ & \\
\hline \multirow{2}{*}{$\begin{array}{l}\text { I told a nurse or } \\
\text { doctor about my } \\
\text { assault }(N=60)\end{array}$} & Yes & $3 \%(01)$ & $33 \%(10)$ & \multirow{2}{*}{$\begin{array}{c}9.017 \\
(0.000)\end{array}$} \\
\hline & No & $97 \%(29)$ & $67 \%(20)$ & \\
\hline \multirow{2}{*}{$\begin{array}{l}\text { I told a local } \\
\text { NGO about } \\
\text { my assault } \\
(N=60)\end{array}$} & Yes & $10 \%(03)$ & $20 \%(06)$ & \multirow{2}{*}{$\begin{array}{c}1.176 \\
(0.236)\end{array}$} \\
\hline & No & $90 \%(27)$ & $80 \%(24)$ & \\
\hline
\end{tabular}

$x^{2}$, Chi-square; $p$-value, the attained level of significance; NGO, non-governmental organization. 
A comparison of the mean scores of the sexually- and physically-assaulted individuals across the Intrusive Thoughts items of the PTSD checklist (items 1 to 5) (Table 3) shows that both types of assaults had similar responses related to repeated disturbing memories, dreams, reliving the experience and physical reactions such as a pounding heart. However, the significant difference was only noted when they were upset or when something reminded them of that stressful experience. In these instances, sexually-assaulted individuals had a higher mean score.

Table 4 shows a comparison of the mean scores of the sexuallyand physically-assaulted individuals across the Avoidance and/or Numbness items of the PTSD checklist (items 6 to 12). Sexually-assaulted women generally had a significantlyhigher mean score $($ mean $=23.32, \mathrm{SD}=5.43, p<0.001)$ when the mean scores of Avoidance and/or Numbness items were added up. Sexually assaulted persons had significantly higher mean scores in the following items:

- avoiding thinking about or talking about that stressful experience or avoiding having feelings that relate to it $(p=0.001)$

- avoiding activities or situations because they remind you of that stressful experience $(p=0.021)$

- trouble remembering important parts of that stressful experience $(p<0.001)$

TABLE 3: Comparison of the mean scores of sexually- and physically-assaulted individuals across the Intrusive thoughts items of the PTSD checklist.

\begin{tabular}{|c|c|c|c|c|c|c|c|}
\hline Measures of intrusive thoughts & Type of assault & Mean & SD & SE Mean & $t$ & df & Sig. \\
\hline \multirow{2}{*}{$\begin{array}{l}\text { Repeated, disturbing memories, thoughts or images of that stressful } \\
\text { experience? }\end{array}$} & Sexual assault & 4.40 & 1.07 & 0.195 & -0.953 & 58 & - \\
\hline & Physical assault & 4.63 & 0.81 & 0.148 & -0.953 & - & 0.106 \\
\hline \multirow[t]{2}{*}{ Repeated disturbing dreams of that stressful experience? $(N=60)$} & Sexual assault & 3.37 & 1.92 & 0.351 & 1.136 & 58 & - \\
\hline & Physical assault & 2.87 & 1.46 & 0.266 & 1.136 & - & 0.000 \\
\hline \multirow{2}{*}{$\begin{array}{l}\text { Suddenly acting or feeling as if that stressful experience was happening } \\
\text { again as if you were reliving it? }(N=59)\end{array}$} & Sexual assault & 3.59 & 1.70 & 0.316 & 1.518 & 57 & - \\
\hline & Physical assault & 2.97 & 1.43 & 0.260 & 1.513 & - & 0.335 \\
\hline $\begin{array}{l}\text { Feeling very upset when something reminded you of that stressful } \\
\text { experience? }\end{array}$ & Sexual assault & 4.33 & 1.39 & 0.255 & 2.726 & 58 & - \\
\hline \multirow{2}{*}{$\begin{array}{l}\text { Having physical reactions such as heart pounding, trouble breathing or } \\
\text { sweating when something reminded you of that stressful experience? }\end{array}$} & Sexual assault & 4.53 & 0.82 & 0.150 & -1.482 & 58 & - \\
\hline & Physical assault & 4.83 & 0.75 & 0.136 & -1.482 & - & 0.014 \\
\hline \multirow[t]{2}{*}{ Intrusive thoughts (PTSD items 1 to 5 ). } & Sexual assault & 20.45 & 3.41 & 0.633 & 1.862 & 57 & - \\
\hline & Physical assault & 18.60 & 4.17 & 0.761 & 1.868 & - & 0.137 \\
\hline
\end{tabular}

PTSD, post-traumatic stress disorder; SD, standard deviation; SE mean, standard error mean; $t$, Student's $t$ variable; df, degree(s) of freedom; Sig., attained level of significance.

TABLE 4: Comparison of the mean scores of sexually- and physically-assaulted individuals across the avoidance and/or numbness items of the PTSD checklist.

\begin{tabular}{|c|c|c|c|c|c|c|c|}
\hline Measures of avoidance and/or numbness & Type of assault & Mean & SD & SE Mean & $t$ & df & Sig. (2-tailed) \\
\hline \multirow{2}{*}{$\begin{array}{l}\text { Avoiding thinking about or talking about that stressful experience or } \\
\text { avoiding having feelings related to it? }\end{array}$} & Sexual assault & 3.17 & 1.67 & 0.310 & 3.376 & 57 & 0.001 \\
\hline & Physical assault & 1.80 & 1.48 & 0.264 & - & - & - \\
\hline \multirow{2}{*}{$\begin{array}{l}\text { Avoiding activities or situations because they remind you of that } \\
\text { stressful experience? }\end{array}$} & Sexual assault & 2.52 & 1.97 & 0.367 & 2.371 & 57 & 0.021 \\
\hline & Physical assault & 1.53 & 1.11 & 0.202 & - & - & - \\
\hline \multirow[t]{2}{*}{ Trouble remembering important parts of that stressful experience? } & Sexual assault & 3.07 & 1.43 & 0.262 & 6.183 & 58 & 0.000 \\
\hline & Physical assault & 1.27 & 0.69 & 0.126 & - & - & - \\
\hline \multirow{2}{*}{$\begin{array}{l}\text { Loss of interest in things that you used to enjoy because of that } \\
\text { stressful experience? }\end{array}$} & Sexual assault & 4.30 & 0.95 & 0.174 & 9.220 & 58 & 0.000 \\
\hline & Physical assault & 1.67 & 1.24 & 0.227 & - & - & - \\
\hline \multirow{2}{*}{$\begin{array}{l}\text { Feeling distant or cut off from other people because of that stressful } \\
\text { experience? }\end{array}$} & Sexual assault & 4.33 & 1.21 & 0.221 & -0.103 & 58 & 0.919 \\
\hline & Physical assault & 4.37 & 1.29 & 0.237 & - & - & - \\
\hline \multirow{2}{*}{$\begin{array}{l}\text { Feeling emotionally numb or being unable to have loving feelings for } \\
\text { those close to you because of that stressful experience? }\end{array}$} & Sexual assault & 3.13 & 1.81 & 0.331 & -2.070 & 58 & 0.043 \\
\hline & Physical assault & 4.03 & 1.54 & 0.282 & - & - & - \\
\hline \multirow{2}{*}{$\begin{array}{l}\text { Feeling as if somehow your future will be cut short because of that } \\
\text { stressful experience? }\end{array}$} & Sexual assault & 2.83 & 1.66 & 0.304 & -3.151 & 58 & 0.003 \\
\hline & Physical assault & 3.93 & 0.94 & 0.172 & - & - & - \\
\hline \multirow[t]{2}{*}{ Avoidance and/or Numbness (PTSD items 6 to 12 ). } & Sexual assault & 23.32 & 5.43 & 1.026 & 3.949 & 56 & 0.000 \\
\hline & Physical assault & 18.60 & 3.53 & 0.646 & - & - & - \\
\hline
\end{tabular}

PTSD, post-traumatic stress disorder; SD, standard deviation; SE mean, standard error mean; $t$, Student's $t$ variable; df, degree(s) of freedom; Sig., attained level of significance.

TABLE 5: Comparison of the mean scores of sexually- and physically-assaulted individuals across the arousal items of the PTSD checklist.

\begin{tabular}{|c|c|c|c|c|c|c|c|}
\hline Measures of arousal & Type of assault & Mean & SD & SE Mean & $t$ & df & Sig. (2-tailed) \\
\hline \multirow[t]{2}{*}{ Trouble falling or staying asleep because of that stressful experience. } & Sexual assault & 3.70 & 1.84 & 0.34 & -3.024 & 58 & 0.004 \\
\hline & Physical assault & 4.80 & 0.76 & 0.14 & - & - & - \\
\hline \multirow{2}{*}{$\begin{array}{l}\text { Feeling irritable or having angry outbursts because of that stressful } \\
\text { experience. }\end{array}$} & Sexual assault & 3.60 & 1.79 & 0.33 & -3.187 & 58 & 0.002 \\
\hline & Physical assault & 4.77 & 0.89 & 0.16 & - & - & - \\
\hline \multirow[t]{2}{*}{ Having difficulty concentrating because of that stressful experience. } & Sexual assault & 4.10 & 1.52 & 0.28 & 3.766 & 58 & 0.000 \\
\hline & Physical assault & 2.73 & 1.28 & 0.24 & - & - & - \\
\hline $\begin{array}{l}\text { Being 'super alert', watchful or on guard because of that stressful } \\
\text { experience? }\end{array}$ & Sexual assault & 4.07 & 1.41 & 0.26 & -2.503 & 58 & 0.015 \\
\hline \multirow[t]{2}{*}{ Feeling jumpy or easily startled because of that stressful experience? } & Sexual assault & 3.83 & 1.51 & 0.28 & -3.130 & 58 & 0.003 \\
\hline & Physical assault & 4.80 & 0.76 & 0.14 & - & - & - \\
\hline \multirow[t]{2}{*}{ Arousal (PTSD items 13 to 17 ). } & Sexual assault & 19.30 & 6.71 & 1.23 & -1.989 & 58 & 0.051 \\
\hline & Physical assault & 21.90 & 2.49 & 0.46 & - & - & - \\
\hline
\end{tabular}

PTSD, post-traumatic stress disorder; SD, standard deviation; SE mean, standard error mean; $t$, Student's $t$ variable; df, degree(s) of freedom; Sig., attained level of significance. 
- loss of interest in things that you used to enjoy because of that stressful experience $(p<0.001)$.

By contrast, physically-assaulted persons had significantly higher mean scores in the items:

- feeling emotionally numb or being unable to have loving feelings for those close to you because of that stressful experience $(p=0.043)$

- feeling as if somehow your future will be cut short because of that stressful experience $(p=0.003)$.

Table 5 shows a comparison of the mean scores of the sexually- and physically-assaulted individuals across the Arousal items of the PTSD checklist (items 13 to 17). Physicallyassaulted persons generally had a tendency to score higher when the mean scores of the five arousal items were added. The observed difference in mean was, however, not significant. On the other hand, a significant difference was noted in all five items when considered individually. Physicallyassaulted women had significantly higher mean scores in four of the five items, whilst sexually-assaulted women had a significantly higher mean score with item 15 (having difficulty concentrating because of that stressful experience).

Levels of depression (Table 6) across sexually- and physicallyassaulted individuals revealed that all the physically-assaulted persons were between moderately $(52 \% ; n=14)$ and severely $(44 \% ; n=12)$ depressed. Sexually-assaulted women, however, were moderately $(19 \% ; n=5)$, severely $(26 \% ; n=7)$ and extremely $(41 \% ; n=11)$ depressed. There was a significant difference between the sexually- and physically-assaulted groups $(p=0.001)$. A virgin who was sexually assaulted said:

'I was raped when I was on my way to school in the morning. Since then I could not cope. I stopped going to school, I even attempted suicide as I thought it would be better to die than to live with the stigma of being raped by my neighbour's son. My grandmother rushed me to the hospital after I drank paraffin. Everyone knows that I was raped. How long will this last? It feels as if someone is walking behind me, I am so scarred [sic]! [Crying].' (P1, Female, 18)

Table 7 compares the mean scores of sexually- and physicallyassaulted individuals across 14 subscales of the Brief COPE Inventory. There was a significant difference $(p=0.034)$ in the total scores for sexual assault (Mean $[\mathrm{M}]=64.70)$ and physical assault $(M=59.13)$. Regarding specific coping styles, victims

TABLE 6: Level of depression.

\begin{tabular}{lccc}
\hline Level of depression & \multicolumn{2}{c}{ Type of assault } & Total \\
\cline { 2 - 3 } & Sexual $(\boldsymbol{n}=\mathbf{2 7})$ & Physical $(\boldsymbol{n}=\mathbf{2 7})$ & $\boldsymbol{N}=\mathbf{5 4}$ \\
\hline Normal ups and downs & $7.4 \%(2)$ & - & $3.7 \%(2)$ \\
Mild mood disturbance & $3.7 \%(1)$ & - & $1.9 \%(1)$ \\
Borderline clinical depression & $3.7 \%(1)$ & - & $1.9 \%(1)$ \\
Moderate depression & $18.5 \%(5)$ & $51.9 \%(14)$ & $35.2 \%(19)$ \\
Severe depression & $25.9 \%(7)$ & $44.4 \%(12)$ & $35.2 \%(19)$ \\
Extreme depression & $40.7 \%(11)$ & $3.7 \%(1)$ & $22.2 \%(12)$ \\
\hline$x^{2}(\boldsymbol{p}$-value) & - & - & $\mathbf{2 1 . 0 6 7 ( 0 . 0 0 1 )}$ \\
\hline
\end{tabular}

$x^{2}$, Chi-square; $p$-value, the attained level of significance.

TABLE 7: Comparison of the mean scores of sexually- and physically-assaulted individuals across the subscale of the Brief COPE scale.

\begin{tabular}{|c|c|c|c|c|c|c|c|}
\hline Variable & Kind of assault & Mean & SD & SE Mean & $t$ & df & Sig. (2-tailed) \\
\hline \multirow[t]{2}{*}{ Total Brief COPE score } & Sexual assault & 64.70 & 7.78 & 1.497 & 2.17 & 55 & 0.034 \\
\hline & Physical assault & 59.13 & 11.04 & 2.016 & - & - & - \\
\hline \multirow[t]{2}{*}{ Self-distraction (items 1 \& 19) } & Sexual assault & 5.13 & 1.88 & 0.345 & 2.80 & 58 & 0.007 \\
\hline & Physical assault & 3.77 & 1.89 & 0.345 & - & - & - \\
\hline \multirow[t]{2}{*}{ Active coping (items 2 \& 7) } & Sexual assault & 5.27 & 1.05 & 0.191 & 1.69 & 58 & 0.095 \\
\hline & Physical assault & 4.73 & 1.36 & 0.249 & - & - & - \\
\hline \multirow[t]{2}{*}{ Denial (items 3 \& 8) } & Sexual assault & 3.34 & 0.86 & 0.159 & 0.97 & 57 & 0.336 \\
\hline & Physical assault & 2.97 & 1.92 & 0.351 & - & - & - \\
\hline \multirow[t]{2}{*}{ Substance use (items 4 \& 11) } & Sexual assault & 3.66 & 2.45 & 0.456 & 2.06 & 57 & 0.043 \\
\hline & Physical assault & 2.53 & 1.65 & 0.302 & - & - & - \\
\hline \multirow[t]{2}{*}{ Use of emotional support (items 5 \& 15) } & Sexual assault & 6.77 & 1.54 & 0.282 & -3.21 & 58 & 0.002 \\
\hline & Physical assault & 7.77 & 0.73 & 0.133 & - & - & - \\
\hline \multirow[t]{2}{*}{ Use of instrumental support (items $10 \& 23$ ) } & Sexual assault & 6.60 & 1.10 & 0.201 & -4.14 & 58 & 0.000 \\
\hline & Physical assault & 7.70 & .95 & 0.174 & - & - & - \\
\hline \multirow[t]{2}{*}{ Behavioural disengagement (items 6 \& 16) } & Sexual assault & 4.34 & 2.57 & 0.477 & -0.628 & 57 & 0.533 \\
\hline & Physical assault & 4.70 & 1.71 & 0.311 & - & - & - \\
\hline \multirow[t]{2}{*}{ Venting (items $9 \&$ 21) } & Sexual assault & 4.33 & 1.61 & 0.293 & 4.53 & 58 & .000 \\
\hline & Physical assault & 2.67 & 1.21 & 0.221 & - & - & - \\
\hline \multirow[t]{2}{*}{ Positive reframing (items 12 \& 17) } & Sexual assault & 3.80 & 2.02 & 0.370 & 2.75 & 58 & .008 \\
\hline & Physical assault & 2.57 & 1.38 & 0.252 & - & - & - \\
\hline \multirow[t]{2}{*}{ Planning (items 14 \& 25) } & Sexual assault & 4.23 & 1.63 & 0.298 & -0.33 & 58 & 0.737 \\
\hline & Physical assault & 4.37 & 1.43 & 0.260 & - & - & - \\
\hline \multirow[t]{2}{*}{ Humour (items 18 \& 28) } & Sexual assault & 2.00 & $0.000^{\mathrm{a}}$ & 0.000 & - & - & - \\
\hline & Physical assault & 2.00 & $0.000^{\mathrm{a}}$ & 0.000 & - & - & - \\
\hline \multirow[t]{2}{*}{ Acceptance (items 20 \& 24) } & Sexual assault & 5.57 & 1.67 & 0.306 & 5.41 & 58 & 0.000 \\
\hline & Physical assault & 3.20 & 1.71 & 0.312 & - & - & - \\
\hline \multirow[t]{2}{*}{ Religion (items 22 \& 27) } & Sexual assault & 6.53 & 1.71 & 0.313 & -1.47 & 58 & 0.151 \\
\hline & Physical assault & 7.23 & 1.99 & 0.364 & - & - & - \\
\hline \multirow[t]{2}{*}{ Self-blame (items 13 \& 26) } & Sexual assault & 3.70 & 2.39 & 0.437 & 1.58 & 58 & 0.119 \\
\hline & Physical assault & 2.93 & 1.14 & 0.209 & - & - & - \\
\hline
\end{tabular}

SD, standard deviation; SE mean, standard error mean; $t$, Student's $t$ variable; df, degree(s) of freedom; Sig., attained level of significance.

a, $t$ cannot be computed because the SD of both groups is 0 . 
of sexual assault use self-distraction $(p=0.007)$, substance use $(p=0.043)$, venting $(p=0.000)$, positive reframing $(p=0.008)$ and acceptance $(p=0.000)$ significantly more often. By contrast, victims of physical assault use emotional support $(p=0.002)$ and instrumental support $(p=0.000)$ significantly more often. No differences were noted regarding the use of active coping, denial, behavioural disengagement, planning, humour, religion or self-blame.

Sexually-assaulted women used personal efforts to cope with trauma whilst the physically-assaulted women relied on support from other people as a way of coping with the trauma. A sexually-assaulted participant stated:

'At least I visited a prayer group that supported me in prayer. After fasting and praying I felt like a large weight has been removed from my shoulders.' (P2, Female, 36)

Some indicated that they used alcohol to help them cope with sexual assault.

One participant who was physically assaulted expressed how she was involved in extra-marital affairs:

'I did not plan to have this child but I found myself sleeping with another man who loved me and could listen to me as I told him all my problems.' (P5, Female, 33)

\section{Discussion}

This study examined trauma experienced by sexuallyassaulted women versus that of physically-assaulted women by intimate partners. The objectives of the study were to compare 30 survivors of sexual assault with 30 survivors reporting physical assault in the previous three months with regard to depressive symptoms, PTSD levels and coping.

The demographic characteristics of participants of both forms of assault had a similar educational background and most of them were unemployed. Women who were physically assaulted by their intimate partners were mostly married (77\%; $n=23$ ) whilst the sexually assaulted women were mostly unmarried $(76 \% ; n=23)$. This confirmed the outcomes of the study conducted by Mahoney and Williams (1998) that indicated that married women might not report marital rape as they did not regard it as forced sex but as fulfilling conjugal rights. A majority of women who were sexually assaulted were still attending school - more than those who were physically assaulted. These findings may be attributed to safety measures available at the school or the availability of transport to school. Further research is recommended in this regard.

Findings revealed that the survivors of both sexual and physical assault received support from the SSO from the time that they reported the case until it was finalised in court. This enhanced the journey toward recovery for the survivors. Sexually-assaulted women disclosed sexual assault more often to either a family member, the community or to the police, whilst the physically-assaulted survivors were reluctant to expose themselves to their intimate partners. The physically-assaulted women only reported the case when they felt they had reached breaking point. Some indicated that they reported their partners to the police because they assaulted them and also stopped paying maintenance for their families. According to the Domestic Violence Act, 116 of 1998 (South Africa 1998), physically-assaulted women needed a 'protection order' so that their spouses would stop abusing them. A significant proportion of those women who were physically assaulted were so badly injured that they were hospitalised. Henderson (2000) and Short and Rosenberg (2001) concur that women only sought medical attention when they were badly hurt by their abusive partners. Only a few reported their intimate partners to the community. There is still a cultural belief that women would not report minor physical abuse as they believe that doing so will be hanging their dirty linen in the public. They would thus only report the abuse when severe injuries were inflicted upon them. This finding confirms the under-reporting of cases.

Under-reporting of cases may be attributed to the sociocultural context within which the community views both sexual and physical assaults, especially if they blame the woman. The response of an individual to perceived trauma (sexual and/or physical assault) also influences how she copes. In this study, participants were only those who reported the incidence of either sexual or physical assault to the trauma centre. The trauma centre provides support to survivors, including their family members, and this provides an environment which enhances coping strategies for the survivors. Participants reported that since they had visited the trauma centre they felt better because most of their fears had been allayed through the care and support they received. Cooperation by the traditional leaders and civic member who called the police for most cases of sexual assault was also an indication that most survivors received support from their cultural environment. Family members also took the survivors to the clinic although, in some instances, participants expressed that at first their parents did not believe them, but later accepted that they were telling the truth. This indicates that the environment was made conducive to the recovery of the participants although, according to findings, the sexually-assaulted women needed more support than the physically-assaulted women.

Participants generally expressed themselves as being 'very satisfied' and 'satisfied' with the services they received as they were treated at the trauma centre. The sexually-assaulted women expressed dissatisfaction with both the nurses and the police whereas the physically-assaulted women expressed dissatisfaction with only the police. Those women who said that they were dissatisfied with the police indicated that they were concerned because their cases were not investigated properly or because the police could not find the perpetrator. Van Dijk (2001) found that, in most instances, victims tended to be dissatisfied with the treatment given by the police and they were thus less likely to report crimes to the police. Consequently, they did not get the support they needed. Van Dijk's (ibid) findings differ from the findings of this study because women received support from the trauma 
centre until the case was finalised in court. This encouraged them to report assault as they were then aware of the services available to them.

Extant findings revealed that sexually-assaulted women tended to score higher mean scores when compared with physically-assaulted women with regard to intrusive thoughts such as repeated disturbing dream, acting as if the stressful event was happening all over again and feeling upset when something reminded them of the situation. Ullman and Filipas (2001) argue that PTSD is related to the nature of rape as it is more personally intrusive than any other form of traumatic event and this makes sexual trauma unique. Sexually-assaulted women are more likely to suffer from PTSD if they are exposed to reliving their experiences on a continual basis without the necessary support. Dealing with court cases without the necessary support could expose the women to PTSD. This might be the reason why victims decide to cancel court cases when they drag on for long periods of time. Sexually-assaulted women reported significantlyhigher mean scores on the Avoidance and/or Numbness items of the PTSD checklist - in this regard, a similar study conducted by Butler et al. (1988) found that rape survivors and combat veterans were more likely to experience PTSD than survivors of any other form of traumatic event. A study conducted by Taft et al. (2007) found that women who were exposed to sexual aggression experienced poorer mental health than those who were physically assaulted.

Social workers should thus recognise the symptoms of PTSD (e.g. flashbacks, elevated startle response and intrusive memories) as a signal that battering may be occurring. The similarity between battering and PTSD experienced by combat veterans has been addressed by Brauer (1994), who discussed the psychological similarities between veterans and physically-assaulted women. The tension of never knowing when the abuse will reoccur, of being fearful for one's own life and of feeling responsible for every situation with no escape, is very similar to a war situation as there is no safety anywhere.

Women who were physically assaulted by their intimate partners reported higher mean scores on four of the five arousal items in comparison with those who were sexually assaulted. This could be related to the fact that physicallyassaulted women were in close contact with their abusive partners as $77 \%(n=23)$ indicated that they were living with their abusive partners. Responses such as 'super alert', feeling jumpy, trouble falling asleep and irritability or anger had significantly-higher mean scores in physically-assaulted women than in sexually-assaulted women. Sexuallyassaulted women had a significantly-higher mean score for item 15 (difficulty in concentration). Some studies found that sexual assault may lead to psychobiological mechanisms that may expose women to a greater risk of alterations in regulation of affect, impulses and consciousness (Trickett \& Putnam 1993). This study suggests that sexual assault is more personal whilst physical assault is more interpersonal. This means that if physically-assaulted women are removed from the perpetrators they will be able to recover faster than the sexually-assaulted women. Their stay with the perpetrators may perpetuate continual violence.

Regarding depressive symptoms, it was found that more of the sexually-assaulted women were extremely depressed, compared with only a few of the physically-assaulted women. A study conducted by Frank and Stewart (1984) found that $56 \%$ of raped women were moderately or severely depressed according to the BDI. With the use of a BDI in this study, almost half of the raped women were diagnosed as suffering from a major depressive disorder. Amongst the extremely depressed women who were sexually assaulted there were some who expressed suicidal ideation, one of whom had attempted suicide by drinking paraffin. These findings were supported by research studies (Burnam et al. 1988; Davidson et al. 1996; Kilpatrick et al. 1985) which showed that sexual assault was associated with suicidal ideation and suicidal behaviour. A study conducted by Ullman (2004) also found a strong association between depression and suicidal behaviour amongst sexually-assaulted women. This means that sexually-assaulted women should be observed for suicidal tendencies and continual support should be provided.

Sexually-assaulted women had their own way of coping with trauma which was different from that of women who were physically assaulted. Findings revealed that sexually-assaulted women more often used self-distraction, substance use, venting, positive reframing and acceptance, whilst physically-assaulted women resorted to the use of instrumental and emotional support as a way of coping with trauma. This reveals that the two types of assaults affect women differently and different measures should be considered when support is offered. Recovery amongst the physically-assaulted women was dependent on the support they received especially when they left the perpetrators; for example, if they continued to get financial support for their children and if they are provided a safe place.

\section{Recommendations regarding support for survivors of both physical and sexual trauma}

All women who report sexual assault should be referred to a psychologist for counseling, as a first port of call, although this is not current practice. Sexually-assaulted women should be observed closely for depression and negative coping mechanisms. Support should be provided and care should be taken to avoid secondary revictimisation when the victim is exposed to a situation which reminds her of what happened on a continual basis. They should be supported when going to court to ensure that they are able to deal with the continual reminder of what happened to them. Continual counseling and support is needed for those who have suicidal ideation. Support for sexually-assaulted women should therefore be provided continuously until they are fully recovered. Doctors and nurses who mostly provide physical treatment to sexually-assaulted women should also refer them to a psychologist for screening. 
The screening of physically-assaulted women should be done as coping with the trauma of physical assault depends on the severity of the problem. If dealt with effectively, they may not need counseling services by a psychologist. It is important to provide victims of physical assault with shelter for protection so that, whilst preparing themselves to move away from their abusers, they have accommodation and meals. Formation of support groups of both forms of assault assist victims in realising that the situation did not happen only to them but that there are others who have gone through similar experiences and are also recovering from the situation.

Those who are involved in dealing with both sexually- and physically-assaulted women should collaborate in order to address all the needs of these women so as to ensure an effective recovery, both physically and psychologically.

\section{Recommendations regarding education of professionals and the community}

Those who are involved in dealing with survivors of sexual and physical assault should be educated regarding the importance of psychological support and the fact that the referral of clients should be done as soon as possible. Continual education of the community regarding the creation of an environment which is both supportive and non-judgemental to survivors of both types of assaults should be encouraged. This would allow more openness and encouragement for physically-assaulted women who only speak out when they felt they could not cope with the situation anymore.

Training in forensic health should be provided to healthcare workers in order to ensure that they have knowledge regarding how to provide the necessary care and support to the victims. Inter-professional education of relevant professionals should be encouraged in order to build team work and to facilitate collaboration amongst the members of the team that should provide care and support to victims of both types of assaults.

\section{Recommendations regarding research}

Further research needs to be conducted to confirm psychobiological influences on sexually assaulted women. A study to investigate the levels of PTSD and depression among women who are both sexually and physically abused should be conducted. A similar study should be conducted amongst women who do not report to the clinic to assess the levels of depression, PTSD and their coping styles.

\section{Limitation of the study}

The study was conducted in only one district and the sample was small. Therefore, findings cannot be generalised to other districts in Limpopo Province.

\section{Acknowledgements}

This research was funded by the Fogarty International Center (FIC) NIH; USA Grant Number: CFDA No 93989 UCLA Subaward Number: 2000 GGE 001.

\section{Competing interests}

The authors declare that they have no financial or personal relationship(s) that may have inappropriately influenced them in writing this article.

\section{Authors' contributions}

M.D.M. (North West University) was the principal investigator also wrote the manuscript; S.M. (University of Limpopo); G.E.W. (UCLA-Semel Institute for Neuroscience and Human Behavior) and J.K.W. (UCLA-Semel Institute for Neuroscience and Human Behavior) gave expert advice and addressed ethical issues related to approval of the study; L.M. (North West University) dealt with statistical analysis reformulated tables as requested by reviewers and L.H.W. (University of California) advised on statistical analysis.

\section{References}

Baker, TC., Burgess, A.W., Brickman, E. \& Davis, R.C., 1990, 'Rape victims' concerns about possible exposure to HIV infection', Journal of Interpersonal Violence 5(1), 49-60. $\mathrm{http}: / / \mathrm{dx}$.doi.org/10.1177/088626090005001004

Beck, A.T., Steer, R.A. \& Carbin, M.G., 1988, 'Psychometric properties of the Beck Depression Inventory: twenty-five years of evaluation', Clinical Psychology Review 8(1), 77-100. http://dx.doi.org/10.1016/0272-7358(88)90050-5

Blanchard, E.B., Jones-Alexander, J., Buckley, T.C. \& Forneris, C.A., 1996, 'Psychometric properties of the PTSD checklist (PCL)', Behaviour Research and Therapy 34(8), 669-673. http://dx.doi.org/10.1016/0005-7967(96)00033-2

Brauer, B.A., 1994, Posttraumatic stress disorder in battered women, viewed 17 June 2012 from http://www.lotsofessays.com/essay_search/battered_women_found.html

Bumberry, W., Oliver, J. M. \& McClure, J. N., 1978, 'Validation of the Beck Depression Inventory in a university population using psychiatric estimates as the criterion', Journal of Consulting and Clinical Psychology 46(1), 150-155. http://dx.doi.org/ 10.1037/0022-006X.46.1.150

Burnam, M.A., Stein, J.A., Golding, J.M., Siegel J.M., Sorenson, S.B., Forsythe, A. et al., 1988 , 'Sexual assault and mental disorders in a community population', Journal of Consulting and Clinical Psychology 56(6), 843-850. http://dx.doi.org/10.1037/ 0022-006X.56.6.843

Butler, R.W., 1988, 'Combat-related posttraumatic stress disorder in a nonpsychiatric population', Journal of Anxiety Disorders 2(2), 111-120. http://dx.doi.org/10.1016/ 0887-6185(88)90018-7

Campbell, J.C., 2002, 'Health consequences of intimate partner violence', Lancet 359 (9314), 1331-1336. http://dx.doi.org/10.1016/S0140-6736(02)08336-8

Carver, C.S., 1997, 'You want to measure coping but your protocol's too long: consider the brief COPE', International Journal of Behavioral Medicine 4(1), 92-100. http:// dx.doi.org/10.1207/s15327558ijbm0401_6

Davidson, J.R., Hughes, D.C., George, L.K. \& Blazer, D.G., 1996, 'The association of sexual assault and attempted suicide within the community', Archives of General Psychiatry 53(6), 550-555. http://dx.doi.org/10.1001/archpsyc.1996.01830060096013

Dye, E. \& Roth, S., 1990 'Psychotherapists' knowledge about and attitudes toward sexual assault victim clients', Psychology of Women Quarterly 14(2), 191-212. http://dx.doi.org/10.1111/j.1471-6402.1990.tb00014.x

Frank, E. \& Stewart, B.D., 1984, 'Depressive symptoms in rape victims. A revisit', Journa of Affective Disorders 7(1), 77-85. http://dx.doi.org/10.1016/0165-0327(84)90067-3

Heise, L., Moore, K. \& Toubia, N., 1996, 'Defining "coercion" and "consent" crossculturally', SIECUS Report 24(2), 12-14.

Henderson, C.W., 2000, 'ACOG issues guidelines on diagnosis and treatment of PMS', Women's Health Weekly, 5/6, 20-22.

Herman, J.L., Perry, J.C. \& Van der Kolk, B.A., 1989, 'Childhood trauma in borderline personality disorder', American Journal of Psychiatry 146(4), 490-495.

Jewkes, R. \& Abrahams, N., 2002, 'The epidemiology of rape and sexual coercion in South Africa: an overview', Social Science and Medicine 55(7), 1231-1244. http:// dx.doi.org/10.1016/S0277-9536(01)00242-8

Jewkes, R., Penn-Kekana, L., Levin, J., Ratsaka, M. \& Schrieber, M., 1999, “'He must give me money, he mustn't beat me". Violence against women in three South African provinces', Medical Research Council Technical Report, MRC, Pretoria.

Johnson, L.E. \& Benight, C.C., 2003, 'Effects of trauma-focused research on recent domestic violence survivors', Journal of Traumatic Stress 16(6), 567-571. http:// dx.doi.org/10.1023/B:JOTS.0000004080.50361.f3

Kalichman, S.C., Sikkema, K.J., DiFonzo, K., Luke, W. \& Austin, J., 2002, 'Emotional adjustment in survivors of sexual assault living with HIV-AIDS', Journal of Traumatic Stress 15(4), 289-296. http://dx.doi.org/10.1023/A:1016247727498

Killian, S., Suliman, S., Fakier, N. \& Seedat, S., 2007, 'Rape survivors and the provision of HIV post-exposure prophylaxis', South African Medical Journal 97(8), 585-586. 
Kilpatrick, D.G., Best, C.L., Veronen, L.J., Amick, A.E., Villeponteaux, L.A. \& Ruff, G.A 1985 , 'Mental health correlates of criminal victimization: A random community survey', Journal of Consulting and Clinical Psychology 53(6), 866-873. http://dx.doi. survey', Journal of Consulting and Clini
org/10.1037/0022-006X.53.6.866

Lebowitz, L. \& Roth, S., 1994, “'I felt like a slut”: The cultural context and women's response to being raped', The Journal of Traumatic Stress 7(3), 363-390. http:// dx.doi.org/10.1002/jts.2490070304

Mahoney, P. \& Williams, L.M., 1998, 'Sexual assault in marriage: prevalence, consequence and treatment of wife rape', in J.L. Jasinski \& L.M. Williams (eds.), Partner violence: a comprehensive review of 20 years of research, pp. 113-162, Sage Publications, Inc., Thousand Oaks, CA.

Moult, K. \& Artz, L., 2011, 'It'Il take more than the pink shorts to tackle violence against women', Monday Paper, 30.03, 11 March, viewed 17 September 2013, from www. uct.ac.za/mondaypaper/archives/?id=8508

McCloskey, L., 1997, 'The continuum of harm: girls and women at risk for sexual abuse across the life span', in D. Ciccetti \& S.L. Toth (eds.), Rochester symposium on across the life span', in D. Ciccetti \& S.L. Toth (eds.), Rochester symposium on developmental psychopathology. Developmental perspectives on trauma: theory,
research and intervention, Vol. 8, pp. 553-578, Rochester University Press, New York.

Regehr, C., Marziali, E. \& Jansen, K., 1999, 'A qualitative analysis of strengths and vulnerabilities in sexually assaulted women', Clinical Social Work Journal 27(2), 171-184. http://dx.doi.org/10.1023/A:1022822823821

Robertson, M., 1998, An overview of rape in South Africa, Centre for the Study of Violence and Reconciliation, Johannesburg.

Roth, S., Newman, E., Pelcovitz, D., Van der Kolk, B. \& Mandel, F.S., 1997, ‘Complex PTSD in victims exposed to sexual and physical abuse: results from the DSM-IV Field Trial for posttraumatic stress disorder', Journal of Traumatic Stress 10(4), 539-555. http://dx.doi.org/10.1002/jts.2490100403

Seymour, J., 2002, 'Domestic violence against British women', Contemporary Review 280(1633), 83-85.

Short, L.M. \& Rosenberg, M.L., 2001, 'Intervening with victims of intimate partner violence', Injury Control and Safety Promotion 8(2),63-69. http://dx.doi.org/10.1076/ icsp. 8.2.63.3363
South Africa, 1998, Domestic Violence Act, 1998 (Act No. 116 of 1998), viewed 23 May 2012, from http://www.acts.co.za/domestic-violence-act-1998/

SPSS version 16.0, 2007, computer software, SPSS Inc., Chicago, IL.

Taft, C.T., Resick, P.A., Panuzio, J., Vogt, D.S. \& Mechanic, M.B., 2007, 'Coping among victims of relationship abuse: a longitudinal examination', Violence and Victims 22(4), 408-418. http://dx.doi.org/10.1891/088667007781553946

Trickett, P.K. \& Putnam, F.W., 1993, 'Impact of child sexual abuse on females: toward a developmental, psychobiological integration', Psychological Science 4(2), 81-87. http://dx.doi.org/10.1111/j.1467-9280.1993.tb00465.x

Ullman, S.E., 2004, 'Sexual assault, victimization and suicidal behaviour in women: A review of the literature', Aggression and Violent Behavior 9(4), 331-351. http:// dx.doi.org/10.1016/S1359-1789(03)00019-3

Ullman, S.E. \& Brecklin, L.R., 2002, 'Sexual assault history, PTSD, and mental health service seeking in a national sample of women', Journal of Community Psychology 30(3), 261-279. http://dx.doi.org/10.1002/jcop.10008

Ullman, S.E. \& Filipas, H.H., 2001, 'Predictors of PTSD symptom severity and socia reactions in sexual assault victims', Journal of Traumatic Stress 14(2), 369-389. http://dx.doi.org/10.1023/A:1011125220522

Van Dijk, J.J.M., 2001, 'Attitudes of victims and repeat victims toward the police: Results of the International Crime Victims Survey', in G. Farrell \& K. Pease (eds.), Repeat victimization, pp. 27-52.

Weist, M.D., Pollitt-Hill, J., Kinney, L., Bryant, Y., Anthony, L. \& Wilkerson, J., 2007, Sexual assault in Maryland: the African American experience, Rockville, MD, National Institute of Justice.

Wiebe, E.R., Comay, S.E., McGregor, M. \& Ducceschi, S., 2000, 'Offering HIV prophylaxis to people who have been sexually assaulted: 16 months' experience in a sexual assault service', Canadian Medical Association Journal 162(5), 641-645.

Zierler, S., Witbeck, B. \& Mayer, K., 1996, 'Sexual violence against women living with or at risk for HIV infection', American Journal of Preventive Medicine 12(5), 304-310. 